\title{
RUANG TERBUKA HIJAU DALAM TATA RUANG KOTA BANDUNG AKHIR ABAD XIX HINGGA PERTENGAHAN ABAD XX
}

\author{
Miftahul Falah, Agusmanon Yuniadi, dan Rina Adyawardhina \\ Departemen Sejarah dan Filologi, Fakultas Ilmu Budaya, Universitas Padjadjaran \\ Jalan Ir. Soekarno KM 21, Jatinangor, Sumedang 45636 \\ E-mai:miftahul.falah@unpad.ac.id; agusmanon@unpad.ac.id;adyawardhina@unpad.ac.id
}

\begin{abstract}
ABSTRAK. Dalam tata ruang kota, ruang terbuka hijau merupakan salah satu komponen pembentuk fisik kota dan keberadaannya menjadi salah satu indikator penilaian terhadap kualitas lanskap kota. Di Kota Bandung, ruang terbuka hijau cukup banyak baik yang dibangun pada masa kolonial maupun masa kemerdekaan, tetapi secara historis, belum banyak yang mengkaji. Bagaimana keletakan ruang terbuka hijau dalam konstelasi tata ruang Kota Bandung pada Abad XX? Untuk memperoleh jawaban atas pertanyaan itu, dalam kajian ini diterapkan metode sejarah yang dalam tataran operasional terdiri atas empat tahap, yaitu heuristik, kritik, interpretasi, dan historiografi. Untuk menganalisisnya, digunakan konsep morfologi kota yakni salah satu pendekatan dalam mengkaji kota dengan menekankan pada aspek perubahan fisik kota. Hasil penelitian menunjukkan bahwa pada masa Pemerintahan Gemeente Bandung (Pemerintah Kota Bandung), ruang terbuka hijau lebih banyak dibangun di wilayah Bandung Utara; hutan kota yang ada Kota Bandung yang dikenal dengan nama Jubileumpark memiliki area lebih luas dibandingkan dengan kondisi sekarang; taman-taman kota yang telah dibangun oleh Pemerintah Gemeente Bandung sebagian besar masih berfungsi setelah direvitalisasi oleh Pemerintah Kota Bandung; dan beberapa taman kota mengalami transformasi karena berbagai alasan, antara lain ketidaksesuaian dengan budaya lokal.
\end{abstract}

Kata kunci: Gemeente Bandung; Ruang Terbuka Hijau; Hutan Kota; Taman Kota

\section{GREEN OPEN SPACE IN BANDUNG'S URBAN PLAN FROM THE LATE 19 TH TO THE MID-20THCENTURY}

\begin{abstract}
In the space of the city, open green space is one of the components of the physical creation of the city and its existence became one of the indicators of assessment of the quality of the urban landscape. In the city of Bandung, both during the colonial period and independence period, green open space has become part of the plan of spatial planning of the city but has not much studied in a historical perspective. How does the green open space change in the spatial layout of Bandung in the 21st century? For answers to questions that, in this study, the history of the methods applied in the operational landscape consists of four stages, namely, heuristics, critique, interpretation, and historiography. The analysis of the study uses the conceptual approach of the city morphology, as one of the approaches in reviewing the city by emphasizing on the physical change of the city. The results showed that during the colonial period, the Government of Gemeente Bandung more build green open space in the area of North Bandung; Jubilleumpark is a city forest that was inaugurated in commemoration of the establishment of the Government of Gemeente Bandung with a wider area than the current condition; the city parks that have been built by the Government of Gemeente Bandung are largely still functioning after being revitalized by the Bandung city government; and some of the city's parks are undergoing transformation for various reasons, such as inconsistency with local cultures.
\end{abstract}

Keywords: Gemeente Bandung; the Green open space; Forest City; Garden City

\section{PENDAHULUAN}

Beberapa tahun terakhir, Pemerintah Kota Bandung gencar membangun taman kota sebagai bagian dari upaya mempercantik kota, memenuhi persentase ruang terbuka hijau terhadap luas wilayah, dan sebagai media memperbanyak area bercengkerama warga kota. Secara historis, keberadaan ruang terbuka hijau bukanlah sesuatu yang baru, tetapi sudah ada sejak masa kolonial. Akan tetapi, pembangunan ruang terbuka hijau pada masa ini, lebih ditujukan untuk kepentingan penduduk dari golongan Belanda atau Eropa lainnya.

Pada masa kolonial, terdapat taman kota yang dibangun untuk menghormati tokoh yang dianggap berjasa. Ada juga taman yang dibangun dengan merujuk pada peristiwa tertentu atau tema tertentu. Taman kota yang dibangun mayoritas terletak di wilayah Bandung
Utara dan hampir dapat dikatakan bahwa di wilayah Bandung Selatan tidak pernah dibangun ruang terbuka hijau kecuali kawasan Tegallega. Mengapa hal tersebut bisa terjadi?

Pada masa kemerdekaan, ruang terbuka hijau tidak terlalu diprioritaskan sebagai komponen penataan kota. Selain "membiarkan" taman kota yang sudah ada, sebagain taman kota bahkan ada yang bertranformasi dengan berbagai alasan. Kondisi tersebut bukan tanpa alasan karena pada masa transisi (1945-1950), bangsa Indonesia tidak memiliki ahli di bidang penataan kota. Akibatnya, perkembangan kota seakan-akan terjadi tanpa melalui perencanaan. Kondisi tersebut diperparah dengan semakin bertambahnya penduduk Kota Bandung sehingga diperlukan pembangunan perumahan bagi penduduk Kota Bandung. Dampaknya adalah ruang terbuka hijau memperlihatkan kecenderungan semakin menyusut karena 
lahan terbuka banyak difungsikan sebagai kawasan pemukiman.

Menyempitnya ruang terbuka hijau mengakibatkan julukan Bandung Kota Kembang terlebih julukan the Garden of Allahseakan hilang maknanya(Indira dkk., 2013: 47) ). Untuk mengembalikan "hijaunya" Kota Bandung, bukan berarti tidak ada upaya dari Pemerintahan Kota Bandung. Akan tetapi, pada masa Pemerintahan Walikota Ridwan Kamil (2013-2018), pembangunan ruang terbuka hijau dirasakan cukup gencar. Selain merevitalisasi taman kota warisan kolonial, beberapa ruang terbuka, seperti trotoar, persimpangan jalan, atau batas jalan dijadikan sebagai ruang terbuka hijau. Meskipun belum mecapai luas ideal, tetapi hal itu menunjukkan bahwa Kota Bandung, sebagai nama resmi (domain) milik Pemerintah Kota Bandung berdasarkan No. 15 Tahun 2001 tentang Merek (Amirulloh, 2017), masih memiliki peluang untuk amanat perundangan-undangan yang mengharuskan luas ruang terbuka hijau minimal 20\% dari luas wilayahnya.

Pemerintah Kota Bandung mulai menyebar proses pembangunan ruang terbuka hijau. Di wilayah Bandung Utara, selain mempercantik taman-taman kota yang sudah ada, pemerintah pun membangun taman kota baru meskipun tidak seluas yang sudah ada. Pembangunan ruang terbuka hijau dilakukan juga di wilayah Bandung Selatan, Bandung Timur, dan Bandung Barat. Hal tersebut menunjukkan keinginan dari Pemerintah Kota Bandung untuk membangun ruang terbuka hijau di setiap wilayah administrasi pemerintahannya. Keinginan tersebut tidak terlepas dari sisi historis bahwa pada masa kolonial, ruang terbuka hijau hanya di bangun di wilayah Bandung Utara. Mengapa hal tersebut dapat terjadi?

Kajian mengenai tata ruang Kota Bandung sudah banyak dilakukan, tetapi rata-rata bukan dari disiplin ilmu sejarah. Para planolog atau arsitek sudah banyak yang mengupas ruang terbuka hijau di Kota Bandung dalam kontelasi tata ruang kota. Sampai tahun 2011, beberapa taman kota yang ada di Kota Bandung belum mencerminkan suatu taman yang layak bagi anak-anak. Tidak hanya itu, beberapa taman bahkan menjadi "rumah" bagi pengemis atau tuna wisma sehingga menghilangkan kenyamaan dan keamanan bagi warga Kota Bandung yang hendak menikmati taman (Dewiyanti, 2011). Apabila dikaitkan dengan tingkat idealisme ruang terbuka menurut perundang-undangan yang berlaku, sampai tahun 2012, Kota Bandung belum memiliki ruang terbuka yang ideal karena terbentur pada keterbatasan kawasan ruang terbuka. Untuk dapat meningkatkan persentase luas ruang terbuka hijau adalah dengan mengoptimalkan sepadan jalan, optimalisasi penataan jalur koridor komersial, atau dengan memperbanyak taman lingkungan yang bersifat privat (Rahmy, dkk., 2012).

Salah satu faktor yang mengakibatkan belum terwujudnya ruang terbuka yang ideal di Kota Bandung (dan kota-kota besar lainnya di Pulau Jawa) adalah pertambahan kawasan area terbangun. Pembangunan kawasan terbangun dengan sendirinya akan mengubah fungsi ruang terbuka karena mayoritas pembangunan pusat aktivitas warga kota dilakukan di pusat perkotaan yang kemudian secara perlahan menyebar ke daerah pinggiran yang akhirnya membentuk jaringan perkotaan. Konsekuensinya, beberapa lahan terbuka berubah fungsi menjadi kawasan terbangun, yang sebagian sudah ada sejak masa Pemerintahan Hindia Belanda dan sebagian lagi dibangun pada masa Pemerintahan Republik Indonesia (Budiman, 2014).

Menyadari bahwa ruang terbuka hijau semakin menyempit, Pemerintah Kota Bandung berupaya menambah kawasan tersebut dengan membangun dan merevitalisasi kawasan terbuka yang fungsinya tidak jelas atau menjadikan koridor jalan, ruang di bawah jalan layang, dan sepadan jalan sebagai taman kota sehingga menambah persentase luas ruang terbuka. Dalam kurun 2004-2007, pembangunan ruang terbuka hijau dilakukan dengan menjalankan program intensifikasi melalui gerakan reboisasi. Dari tahun 2007-2010, luas ruang terbuka hijau di Kota Bandung mencapai 9,94\% dari luas wilayah Kota Bandung dan satu tahun kemudian menjadi 11,42\% (Puspitojati, 2015). Melalui program revitalisasi taman kota, sampai tahun 2015, di Kota Bandung bermunculan taman "baru" baik yang bertemakan alam, kepahlawanan, kesehatan, seni, olah raga, dan sebagainya (Budiman, 2015). Kurniati (2016) tidak membahas secara khusus ruang terbuka hijau, melainkan menyoroti masalah yang lebih luas, yakni tata ruang kota Kota Bandung dari sudut pandang ilmu komunikasi. Hasil kajiannya menunjukkan bahwa Pemerintah Kota Bandung telah berupaya menyosialisasikan kebijakan penataan ruang kota kepada seluruh lapisan masyarakat. Akan tetapi, dari data yang diperoleh, Poni Sukaesih menyimpulkan bahwa partisipasi masyarakat cukup kurang dan ketersediaan sumber daya manusia yang bisa menunjang penataan ruang kota masih belum cukup ideal, baik secara kuantitas maupun kualitas. Hal tersebut terlihat dari masih lemahnya penegakkan sanksi bagi masyarakat yang melanggar regulasi mengenai tata ruang kota.

\section{METODE}

Metode penelitian yang dipergunakan dalam penelitian ini adalah metode sejarah yakni The process of critically examining and analyzing the records and survivals of the past. The imaginative reconstruction of the past from the data derived by the process is called historiography (Gottschalk, 1968: 48). Dalam tataran operasional, metode sejarah dilakukan dalam empat tahap. Pertama heuristik yakni proses mencari, menemukan, dan menghimpun sumber sejarah yang relevan dengan pokok 
masalah. Heuristik merupakan sebuah proses pencarian dan penghimpunan sumber data atau informasi yang bisa didapatkan dari sumber-sumber sejarah yaitu sumber tertulis, sumber lisan, dan sumber benda atau artefak (Gottschalk, 1968; Kuntowijoyo, 1995; Herlina, 2008). Sementara itu, G. J. Renier (1997) membedakan sumber sejarah menjadi dua jenis, yakni sumber material dan sumber immaterial. Selain sejarah lisan dan tradisi lisan, sumber sejarah dimasukkan ke dalam klasifikasi sumber material.

Secara pragmatis, heuristik dilakukan untuk menghimpun sumber yang relevan dengan topik tulisan ini, antara lain Mooi Bandoeng yakni majalah mingguan yang banyak memberitakan kehidupan Kota Bandung pada dalam kurun waktu 1920-1940-an. Mooi Bandoeng banyak menginformasikan keberadaan ruang terbuka hijau di Kota Bandung. Demikian juga dengan terbitan berkala lainnya yakni Groot Bandoeng yang banyak mengupas tentang Kota Bandung. Selain itu, dalam kegiatan heuristik dihimpun juga sumber lainnya, antara lain foto-foto baik yang lama maupun yang baru, peta Kota Bandung, buku, surat kabar, dann sumber internet.

Tahap selanjutnya adalah kritik, baik kritik ekstern maupun kritik intern. Kritik dilakukan untuk memastikan bahwa sumber yang telah dihimpun merupakan sumber otentik sekaligus memiliki tingkat kredibilitas tinggi (Garraghan, 1957; Gottschalk, 1968; Herlina, 2008). Kritik intern dilakukan juga terhadap sumber sezaman yang secara eksternal bersifat ontentik. Hal ini dilakukan untuk menjaga kredibilitas sumber sehingga dapat dipergunakan untuk merekonstruksi peristiwa sejarah. Misalnya, pada peta Kota Bandung yang dibuat tahun 1953, terdapat keterangan (legenda) terkait keberadaan Universitas Padjadjaran. Secara internal, sumber kartografi tersebut patut dipertanyakan kredibilitasnya karena Universitas Padjadjaran baru didirikan pada 1957. Oleh karena informasi yang lainnya benar, peta tersebut tetap dapat dipergunakan karena informasi yang terkandung di dalam peta tersebut tidak bertentangan. Dengan demikian, peta tersebut tetap dapat dipergunakan sebagai sumber sejarah yang kredibel karena bisa jadi kesalahannya hanya pada penulisan angka tahun reproduksi peta tersebut, bukan pada informasi (isi) peta secara keseluruhan. Kritik yang dilakukan menghasilkan serangkaian fakta yang kemudian diinterpretasi baik secara verbalistis, teknis, faktual, logis, maupun psikologis (Garraghan, 1957; Herlina, 2008). Hasil penafsiran yang bersifat kronologis, menjadi dasar merekonstruksi kisah masa lampau yang kemudian dinamai historiografi (Gottschlak: 1968; Abdullah, 1984; Kuntowijoyo, 1995; Renier, 1997; Herlina, 2008; Sofianto, 2014). Historiografi dalam tulisan ini diberi judul Ruang Terbuka Hijau dalam Tata Ruang Kota Bandung pada Akhir Abad XIX hingga Pertengahan Abad XX.

Untuk keperluan eksplanasi sejarah, kajian dalam tulisan ini menggunakan pendekatan morfologi kotasehinggabentuk logis sebuah kota sebagai produk perubahan sosio-spatial dapat dipahami baik secara historis, sosiologis, maupun teknis. Morfologi kota tidak hanya membicarakan mengenai bentuk fisik kota, melainkan juga membahas berbagai komponen pembentuk fisik kota, yang salah salah satu di antaranya adalah ruang terbuka. Secara konseptual, ruang terbuka didefinisikan sebagai "any urban ground space,regardless of public accessibility, that is not roofed by an architectural structure" (Stanley et al., 2012: 1089). Ruang terbuka merupakan salah komponen pembentuk fisik kota yang saling memengaruhi dengan komponen lainnya, seperti bangunan, sirkulasi jalan, pusat ekonomi, dan sebagainya.

Secara konseptual, ruang terbuka dibagi menjadi dua klasifikasi yaitu ruang terbuka hijau. dan ruang terbuka non-hijau. Kedua ruang terbuka tersebut merupakan salah satu bagian penting dari pertumbuhan morfologi kota. Ruang terbuka hijau adalah kawasan permukaan tanah yang didominasi oleh tumbuhan yang berfungsi sebagai perlindungan habitat tertentu dan sarana lingkungan kota atau kawasan perkotaan sehingga bisa dipergunakan untuk meningkatkan kualitas atmosfer, menunjang kelestarian air dan tanah, serta untuk meningkatkan kualitas lanskap kota (Hakim, 2004). Sementara itu, Ruang Terbuka Non-hijau adalah ruang yang secara fisik bukan berbentuk bangunan gedung dan tidak dominan ditumbuhi tanaman ataupun permukaan berpori, dapat berupa perkerasan, badan air, ataupun kondisi tertentu lainnya (Indonesia, 2009)

\section{Ruang Terbuka Hijau Masa Pemerintahan Gemeente Bandung}

Setelah menjadi pusat pemerintahan Kabupaten Bandung pada 25 September 1810, tidak dapat dipungkiri bahwa Kota Bandung semakin memegang peranan penting. Peran politik Kota Bandung semakin bertambah ketika dijadikan sebagai pusat pemerintahan Keresidenan Priangan menggantikan Kota Cianjur, berdasarkan Besluit van Gouverneur Generaal van Nederlandsche-Indie van 11 October 1856, No. 84. Meskipun demikian, realisasi besluit itu baru dilaksanakan 7 Agustus 1864 sering dengan terbitnya Besluit van Gouverneur Generaal van Nederlandsche-Indie van 7 Augustus 1864, No. 18 (Staatsblad van Nederlandsche-Indie 1864 Nomor 114). Sejak menjadi pusat pemerintahan Keresidenan Priangan, Kota Bandung tumbuh menjadi pusat politik, ekonomi, sosial, dan budaya. Pertumbuhan Kota Bandung semakin meningkat sejalan dengan adanya wacana menjadikan kota ini sebagai pusat pemerintahan Hindia Belanda. Wacana tersebut diawali dengan pembangunan dua gedung militer, yaitu Paleis Legercommandant (rumah dinas Panglima Tentara Hindia Belanda) dan Departement van Oorlog (Departemen Peperangan). Dalam tata ruang Kota Bandung, wilayah di sekitar kedua bangunan tersebut kemudian menjadi kawasan militer. 
Wacana menjadikan Kota Bandung sebagai pusat pemerintahan Hindia Belanda, direspons oleh Pemerintah Gemeente Bandung (Pemerintahan Kota Bandung masa kolonial Belanda) dengan merencanakan perluasan kota ke arah utara rel kereta api. Rencana tersebut didasarkan pada suatu kondisi bahwa sampai awal Abad XX, wilayah Bandung Utara relatif masih kosong dibandingkan dengan kawasan Bandung Selatan. Oleh Pemerintah Gemeente Bandung, wialayah Bandung Utara akan dijadikan sebagai pusat pemerintahan, pusat pemukiman orang-orang Belanda/Eropa, pusat ekonomi, dan pusat sosial-budaya (Falah, 2018: 343).

Konsekuensi logis dari pembangunan pemukiman adalah dibangunnya ruang terbuka hijau untuk memenuhi kebutuhan penduduk Belanda/Eropa. Di kalangan mereka, taman kota merupakan suatu kebutuhan sebagai primer sebagai tempat untuk bercengkerama dengan sesama warga kota dan untuk menikmati keindahan kota, untuk melepaskan kepenatan (Budiman, 2015: 190). Tamantaman yang dibangun di Kota Bandung oleh Pemerintah Hindia Belanda, semuanya berada di wilayah Bandung Utara karena di wilayah inilah pembangunan pemukiman orang-orang Belanda/Eropa dikonsentrasikan, sebagaimana dapat dilihat pada gambar 1 .
Di Kota Bandung, taman kota pertama yang dibangun adalah Pieter Sijthoffpark. Setelah itu, dibangun beberapa taman yang semuanya berada di kawasan Bandung Utara, antara lain Insulinde Park, Molukken Park, Tjibeunjing Plantsoen, Tjilakiplein, Oranjeplein, dan Ijzermanpark. Selain taman-taman tersebut, terdapat juga beberapa taman kecil sehingga pada 1930-an, Kota Bandung acapkali disebut sebagai tuinstad (kota taman) karena keberadaan taman kota menjadikan Bandung sebagai kota yang sangat indah (Mooi Bandoeng, Feb. 1933: 117-119).

\section{Jubileumpark}

Keberadaan hutan kota tidak dimiliki oleh setiap kota pusat pemerintahan di Priangan. Meskipun tidak sebesar Kebun Raya Bogor, di Kota Bandung terdapat sebuah hutan kota yang pada masa kolonial dikenal dengan sebutan Jubileumpark yang mulai dibangun pada 1923 yang terletak di Lembah Cikapundung, yakni antara Lembangweg (berubah menjadi Jalan Cipaganti, sekarang menjadi Jalan R. A. A. Wiranatakusumah III) dan Taman sariweg (sekarang Jalan Tamansari), sebagaimana dapat lihat pada gambar 2 .

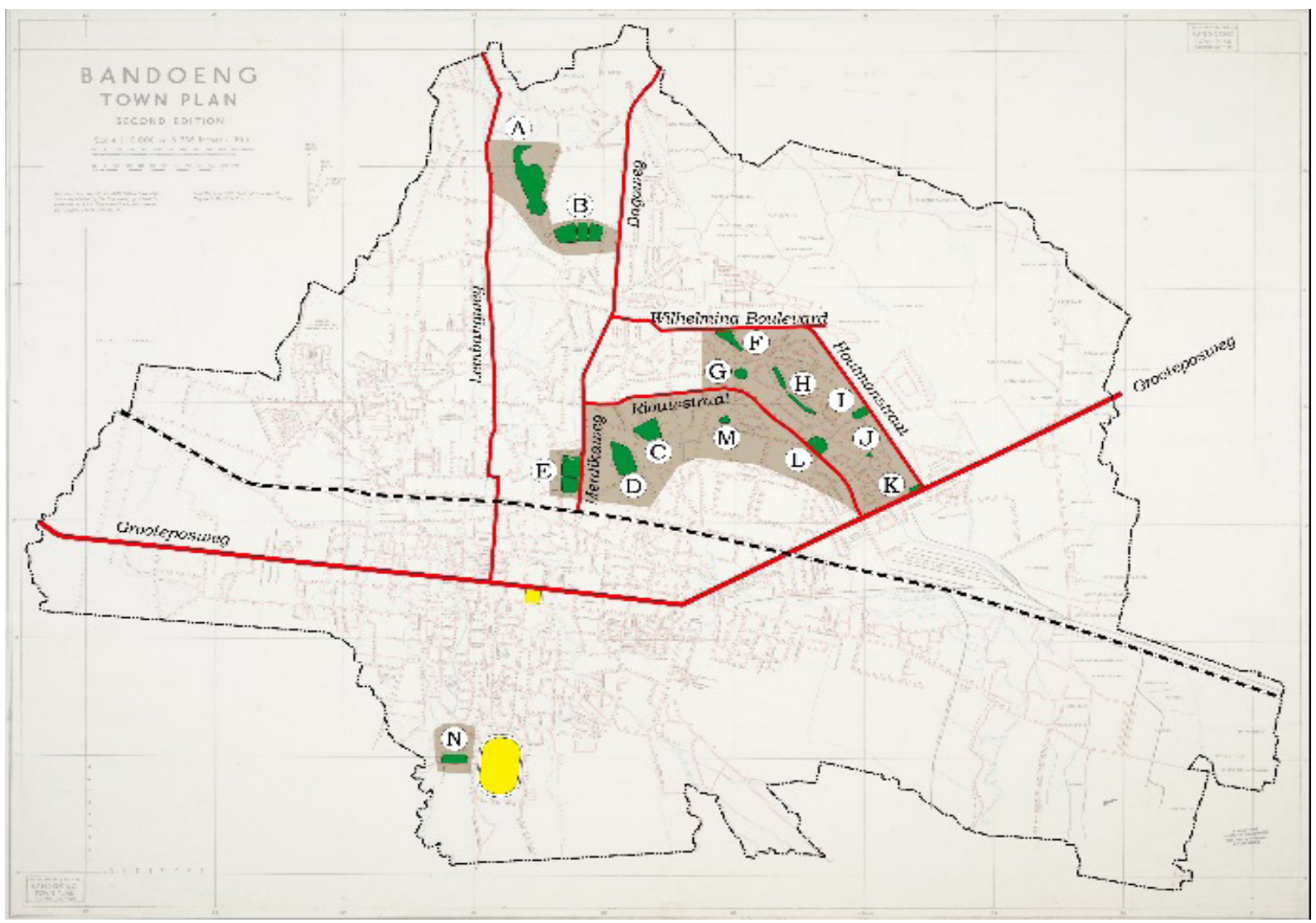

Gambar 1. Keletakan Ruang Terbuka Hijau di Kota Bandung Tahun 1885-1942

Keterangan:

(A) Jubileumpark; (B) Ijzermanpark; (C) Molukkenpark; (D) Insulin depark; (E) Pieters Sijthoffpark; (F) Tjilakiplein; (G) Tjitaroemplein; (H) Tjibeunjing Plantsoen; (I) Houtmanplein; (J) Orchidplein; (K) van Limburg Stirum Plein; (L) Oranje Nassauplein; (M) Sabangplein; (N) P.W.S. Plein.

Sumber: Rekonstruksi oleh Miftahul Falah dari Bandoeng: Town Plan, 1945; Collectie Kaarten van Coloniaal Nederlandsch-Indie. Inv. D E $29,7$. Leiden: Rijskuniversiteit Leiden. 


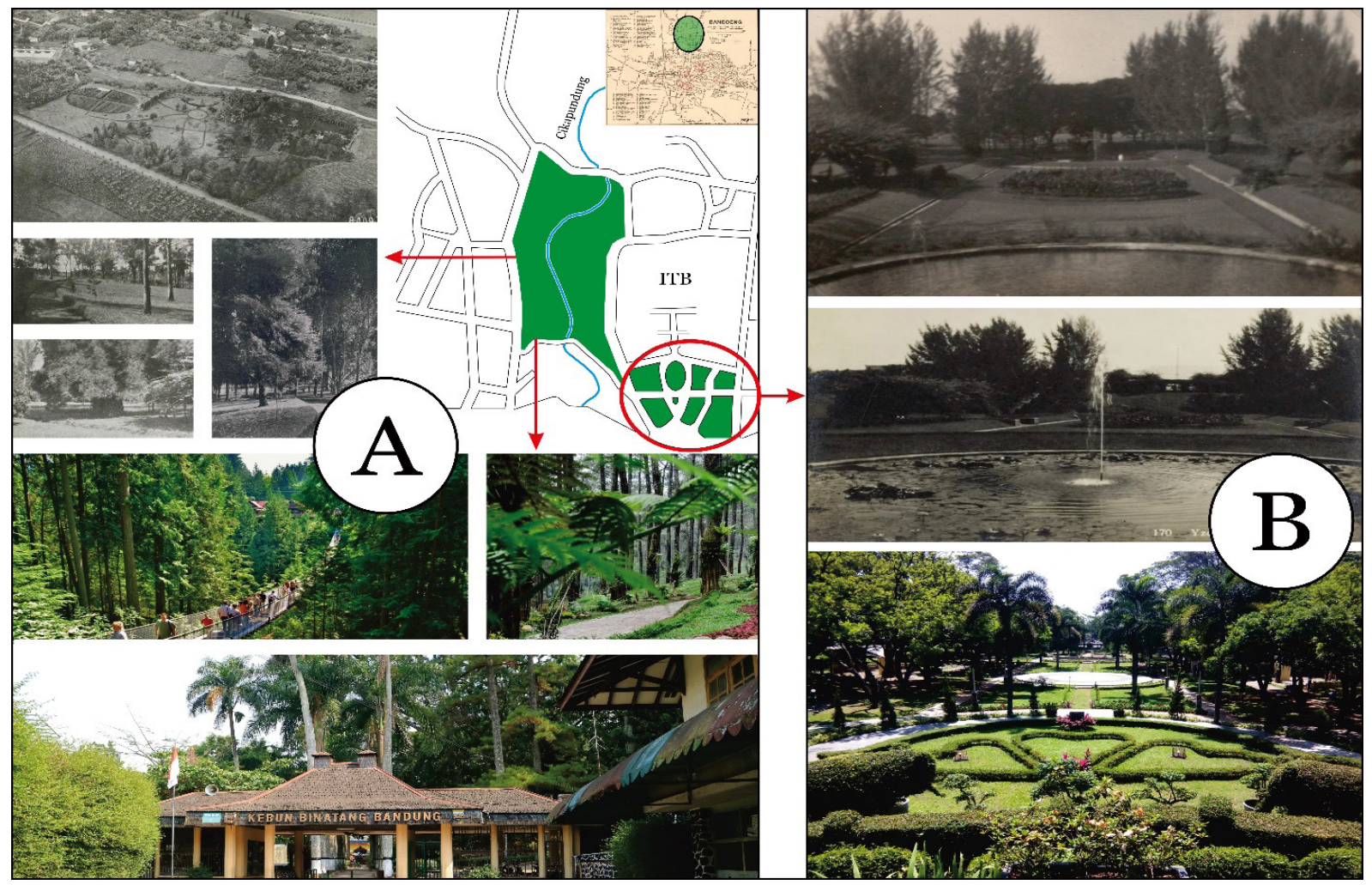

Gambar 2. Keletakan Jubileumpark dan Ijzermanpark

Keterangan : A = Jubileumpark (Kebun Binatang Bandung \& Babakan Siliwangi); B = Iizermanpark (Taman Ganesha ITB)

Sumber: Direkonstruksi oleh Miftahul Falah dari Allied Geographical Section. "Bandoeng (Monash Collections Online).” Diakses dari http://repository.monash. edu/items/show/27141. Tanggal 15 Juli 2019. Pukul 22.37 WIB; "Jubileumpark”. Mooi Bandoeng. Maanblad van Bandoeng en Omstreken. October 1934. Bandoeng: A. C. Nix \& Co.; "Bandoeng als Tuinstad”. Mooi Bandoeng. Maanblad van Bandoeng en Omstreken. Februari 1934. Bandoeng: A. C. Nix \& Co.; Het Ijzermanpark te Bandoeng, 1925. Collectie Koninklijk Insituut Taal-, Land-, en Volkenkunde (KITLV). Inv. Nr. 34882. Leiden: Rijskuniversiteit Leiden; Het Ijzermanpark te Bandoeng, 1930. Collectie Koninklijk Insituut Taal, Land-, en Volkenkunde (KITLV). Inv. Nr. 143590. Leiden: Rijskuniversiteit Leiden; Dokumentasi Penulis, November 2016.

Di kawasan Jubileumpark, terdapat beragam kekayaan flora dan fauna yang selain menjadi tempat berwisata juga memainkan peranan sebagai pusat penelitian kebiologian. Di kawasan Jubileumpark, terdapat juga Zoological Garden. Untuk keperluan pariwisata, Jubileumpark mulai dibuka untuk umum pada 1931 (Mooi Bandoeng, October 1934). Sebagai objek wisata, Pemerintah Gemeente Bandung melakukan pengembangan Zoological Garden. Sampai tahun 1936, pemerintah telah menambah lebih dari 58 satwa (Suganda, 2007: 154; Budiman, 2015: 199). Setelah Indonesia merdeka, Zoological Garden kemudian menjadi Kebun Binatang Bandung dan hingga saat ini menjadi salah satu destinasi wisata utama di Kota Bandung. Wisatawan yang mengunjungi tempat ini, bukan hanya warga Kota Bandung dan wilayah sekitarnya, tetapi banyak juga yang berasal dari luar wilayah Kota Bandung.

Tidak jauh dari Jubileumpark, terdapat sebuah taman yang bernama Ijzermanpark yang pada masa Republik berubah nama menjadi Taman Ganesaha (ITB). Taman ini berlokasi di depan kampus Techniese Hoogeschool (sekarang ITB), di antara jalan Hoogeschoolweg (sekarang Jalan Ganesha) dan Maclaine Pontweg (sekarang Jalan Gelap Nyawang). Meskipun memiliki ukuran jauh lebih kecil jika dibandingkan dengan Jubileumpark, tetapi taman yang dibangun pada 1927 ini sangat indah karena ditata sangat rapih bunga dalam berbagai warna. Di taman ini terdapat juga fitur air segar yang bening diselingi dengan rumput hijau dan pohon kelapa sawit dekoratif. Penataan seperti itu menjadikan Ijzermanpark sebagai salah satu taman dengan lanskap paling bagus pada masanya (Mooi Bandoeng, February 1934).

Setelah Indonesia merdeka, Ijzermanpark berubah nama menjadi Taman Ganesha. Patung dada Ijzerman, salah seorang penggagas didirikannya Techniese Hoogeschool sampai tahun 1950-an masih berdiri tegak. Pada 1960-an, patung itu menghilang dan diganti oleh patung ganesha. Saat ini, di lokasi bekas patung dada Ijzerman dan patung ganesha, dibangun sebuah tugu kontemporer yang terbuat dari baja tahan karat berbentuk rangka kubus (http://aldes91. blogspot.com/2010/01/sejarah-tamankota-di-bandung.html).

\section{Pieters Sijthoffpark}

Di tengah-tengah Kota Bandung (midden in de Stad Bandoeng), pada 1885 dibangun sebuah taman yang kemudian diberi nama Pieters Sijthoffpark yang dirancang oleh R. Teuscher, seorang ahli tanaman (botanikus), 
berlokasi di depan rumah asisten residen (yang pada 1906 berubah menjadi Gemeente Huis). Taman tersebut diberi nama Pieter Sijthoffpark sebagai bentuk penghargaan kepada asisten residen yang telah berjasa dalam pembangunan infrastruktur Kota Bandung (Budiman, 2015: 190; Kunto, 1984: 114). Bentuk tamannya persegi empat, beserta dengan jalanan berbentuk mirip huruf "Y". Sebuah Gazebo ditempatkan di tengah pertemuan jalan taman ini. Kanal taman dengan jembatan penyeberangan artistik yang terbuat dari besi dibangun mengelilingi taman. Berbagai jenis pohon pelindung, pohon hias, tanaman hias, dan bunga-bungaan menambah keindahan taman tersebut (https://portal. bandung.go.id/ taman-kotabandung-tempo-dulu).

Taman sederhana tersebut diberi nama Pieter Sijthoffpark sebagai bentuk penghargaan terhadap Pieter Sijthoff, Asisten Residen Bandung, yang turut berkonstribusi dalam mengambangkan Bandung sebagai Pusat Pemerintahan Keresidenan Priangan. Selain itu, taman ini pun dikenal dengan nama Kebon Raja karena di sebelah timur terdapat Kweekschool yang acapkali disebut dengan istilah Sakola Raja. Pada 1950, Pieter Sijthoffpark (Kebon Raja) berubah nama menjadi Taman Merdeka dan sejak Desember 1996 namanya menjadi Taman Dewi Sartika (https://portal.bandung.go.id/ taman-kotabandung-tempo-dulu).

\section{Insulindepark dan Molukkenpark}

Insulindepark dibangun di atas tanah kosong yang sampai tahun 1918 masih berupa rawa. Setelah dikeringkan dan ditanami pepohonan di sepanjang pinggirannya, pada 1919-1920 tanah tersebut dijadikan sebagai pusat latihan militer. Pada akhir tahun 1920, pemerintah menjadikan lapangan itu sebagai taman tropis yang sampai tahun 1935 telah memiliki sekitar 90 jenis tanaman keras dan aneka bunga. Pada 1925, pemerintah kolonial menamai taman tropis itu sebagai Insulindepark. Setelah Indonesia merdeka, pada 28 April 1950, Pemerintah Kotapraja Bandung mengubah nama Insulindepark menjadi Taman Nusantara. Pada tanggal 1 Maret 1958, namanya berubah lagi menjadi Taman Lalu Lintas. Untuk mengenang korban peristiwa Gerakan 30 September, Taman Nusantara berubah nama menjadi Taman Lalu Lintas Ade Irma Suryani Nasution (https:// portal.bandung.go.id/ taman-kota-bandung-tempo-dulu).

Sementara itu, Molukkenpark dibangun oleh Pemerintah Gemeente Bandung pada 1919 yang berlokasi di kawasan militer, tepatnya di antara Menadostraat (Jalan Menado), Celebesstraat (Jalan Sumatera), Ambonstraat (Jalan Ambon), dan Saparuastraat (Jalan Saparua). Pada saat, Molukkenpark ditata dan dilengkapi dengan sebuah kolam besar berhiaskan air mancur, bunga teratai, tanaman hias, pohon pelindung sebagai peneduh, bangku

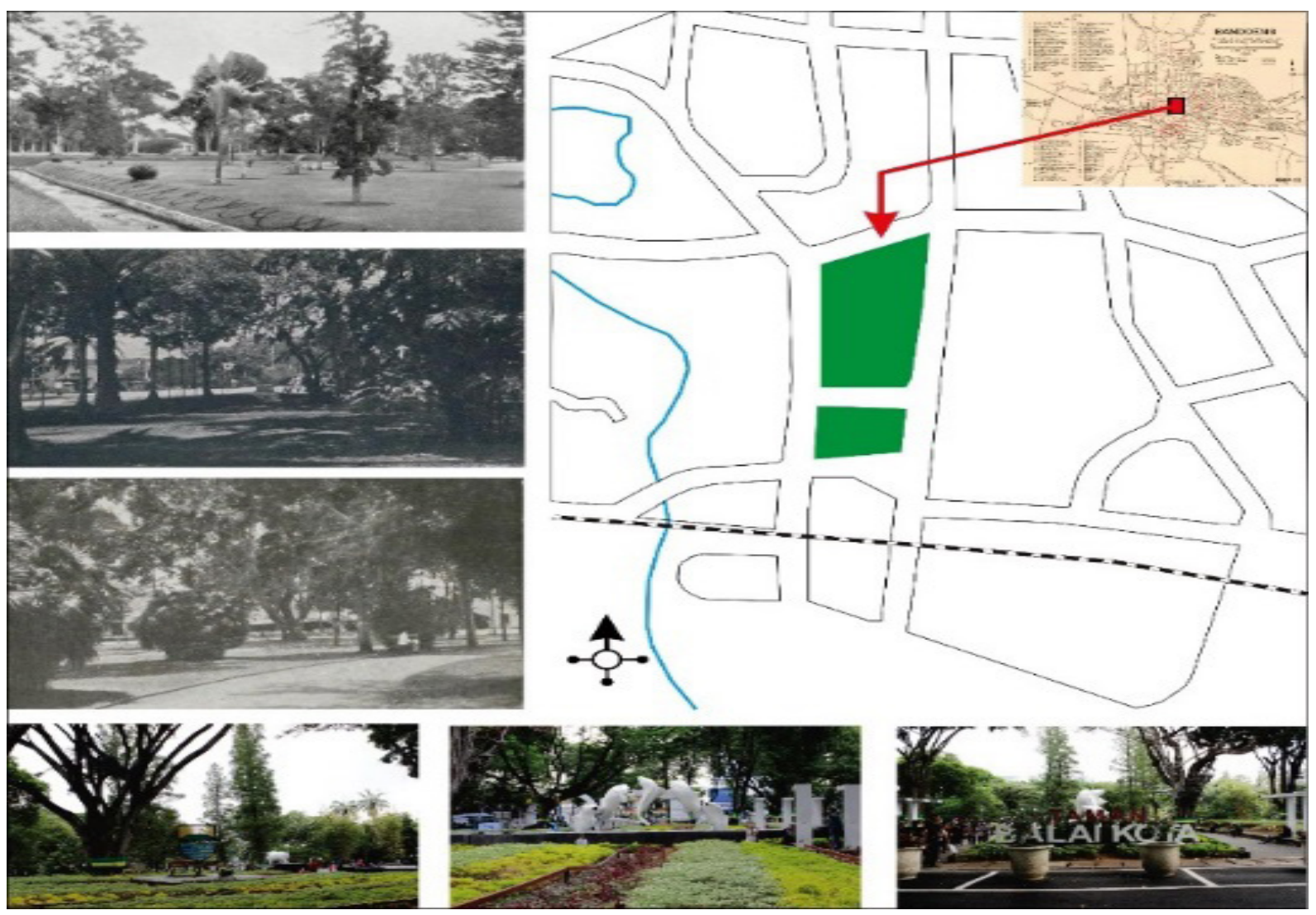

Gambar 3. Keletakan Pieters Sijthoffpark

Sumber: Direkonstruksi oleh Miftahul Falah dari Allied Geographical Section. "Bandoeng (Monash Collections Online).” Diakses dari http://repository. monash.edu/items/show/27141. Tanggal 15 Juli 2019. Pukul 22.37 WIB;; "Pieter Sijthof Park". Mooi Bandoeng. Maanblad van Bandoeng en Omstreken. Jaargang 1. Nr. 8. Feb. 1933. Bandoeng: A. C. Nix \& Co.; "Pieter Sijthof Park". Mooi Bandoeng. Maanblad van Bandoeng en Omstreken. Jaargang 1. Nr. 5. Nov. 1933.. Bandoeng: A. C. Nix \& Co.; Dokumentasi Penulis, 4 Oktober 2015. 


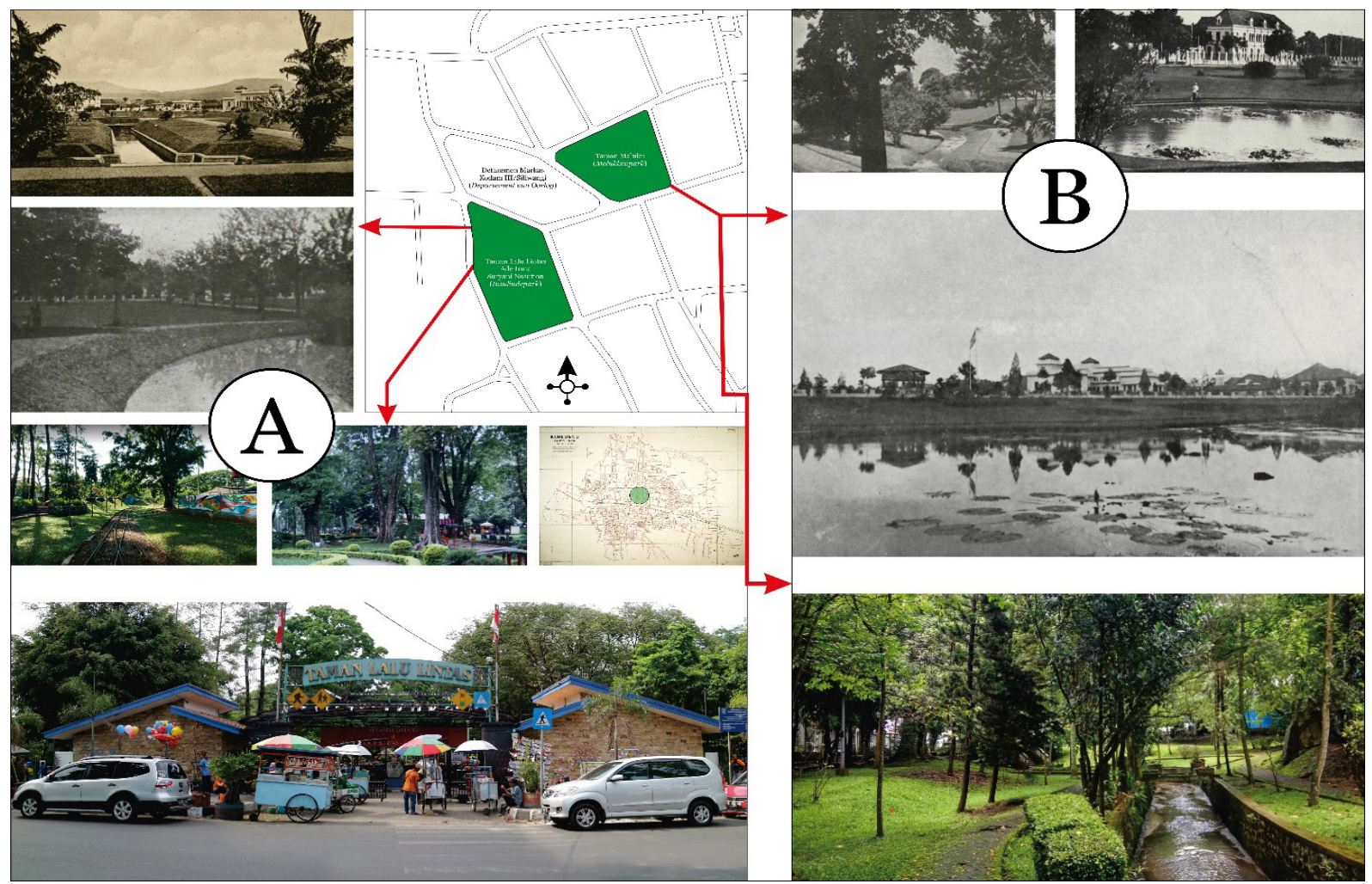

Gambar 4. Keletakan Insulindepark dan Molukkenpark

Keterangan : A = Insulindepark (Taman Lalu Lintas Ade Irma Suryani Nasution); B = Molukkenpark (Taman Maluku)

Sumber: Direkonstruksi oleh Miftahul Falah dari Bandoeng: Town Plan, 1945. Collectie Kaarten van Coloniaal Nederlandsch-Indie. Inv. D E 29,7. Leiden: Rijskuniversiteit Leiden; S. A. Reitsma. 1926. Bandoeng; The Mountain City of Netherlands India. Batavia: G. Kolff.; Bandoengsche Administratie Mij. De Jaarbeurs en Bandoeng 1921. Bandoeng: Visser \& Co.; "Bandoeng als Tuinstad”. Mooi Bandoeng. Maanblad van Bandoeng en Omstreken. Februari 1934. Bandoeng: A. C. Nix \& Co.; "Bandoeng als Tuinstad". Mooi Bandoeng. Maanblad van Bandoeng en Omstreken. Februari 1934. Bandoeng: A. C. Nix \& Co.; Het paleis van de legercommandant aan het Insulinde Park te Bandoeng, 1920. Collectie Koninklijk Insituut Taal-, Land-, en Volkenkunde (KITLV). Inv. Nr. 1400613. Leiden: Rijskuniversiteit Leiden; Dokumentasi Penulis, November 2016.

taman di keteduhan pohon, Jalan taman, dan tiang-tiang lampu berdekorasi artistik, sehingga memberikan kesan sejuk dan asri (dari https:// por- tal.bandung.go.id/tamankota-bandung-tempo-dulu).

\section{Tjilakiplein, Tjibeunjing Plantsoen, Tjitaroemplein, dan Oranje Nassauplein}

Pada awalnya, Tjilakiplein dibuat bukan sebagai taman kota, tetapi lebih cenderung sebagai hutan kota. Hal tersebut bisa dilihat dari penataan pepohonnya yang relatif tidak diatur layaknya sebuah taman. Tjilakiplein terbagi menjadi tiga bagian. Pertama, area utara Tjilakiplein berada pada lokasi di antara Wilhelmina Boulevard (sekarang Jalan Diponegoro) dan Tjimanoekstraat (sekarang Jalan Cimanuk). Kedua, area tengah plein yang berlokasi di antara Tjimanoekstraat dan Tjitaroemstraat (sekarang Jalan Citarum). Ketiga, bagian selatanplein dimulai dari Tjitaroemstraat sampai Tjiliwoengstraat (sekarang Jalan Ciliwung).

Saat ini, ketiga bagian dari Tjilakiplein itu telah direvitalisasi oleh Pemerintah Kota Bandung menjadi tiga buah taman, yaitu Taman Lansia, Taman Kandaga Puspa, dan Pet Park. Di Taman Kandaga Puspa disimpan lebih dari 100.000 spesies tanaman. Oleh karena itu, taman ini selain berfungsi sebagai hutan kota, juga memiliki fungsi edukasi (http:/www.-wisatabdg.com/2014/09/inilah-tamantematik-di-kota-bandung.html). Pada Desember 2014, Kota Bandung memilikitamanbaruyakniPet Park yang berlokasi di Jalan Cilaki, tidak jauh dari Taman Lansia dan Taman Pustaka Bunga, sengaja dibuat untuk warga Kota Bandung yang memiliki kegemaran mengajak hewan peliharaannya "berjalan-jalan menyusuri Kota Bandung. Meskipun demikian, taman ini terbuka untuk warga kota yang tidak memiliki hewan peliharaan (http:// www.wisatabdg.com/ 2014/10/ingin-mengajak-jalan-jalanhewan.html).

Taman lain yang sudah ada pada masa kolonial adalah Tjitaroemplein dibangun oleh Pemerintah Gemeente Bandung untuk mengenai keberhasilan Dr. Ir. De Groot yang berhasil membangun Stasiun Radio Malabar yang diresmikan oleh Gubernur Jenderal de Fock pa 5 Mei 1923. Melalui stasiun ini, komunikasi antara Kerajaan Belanda dan Hindia Belanda dapat dilakukan melalui radio. Untuk mengenang jasa-jasanya itu, dibangun sebuah taman yang diberi nama Tjitaroemplein yang di tengah-tengahnya terdapat monumen bola dunia dan dua orang telanjang sedang melakukan komunikasi (https://mooibandoeng.com/2013/06/ 27/stasiun-radio- 


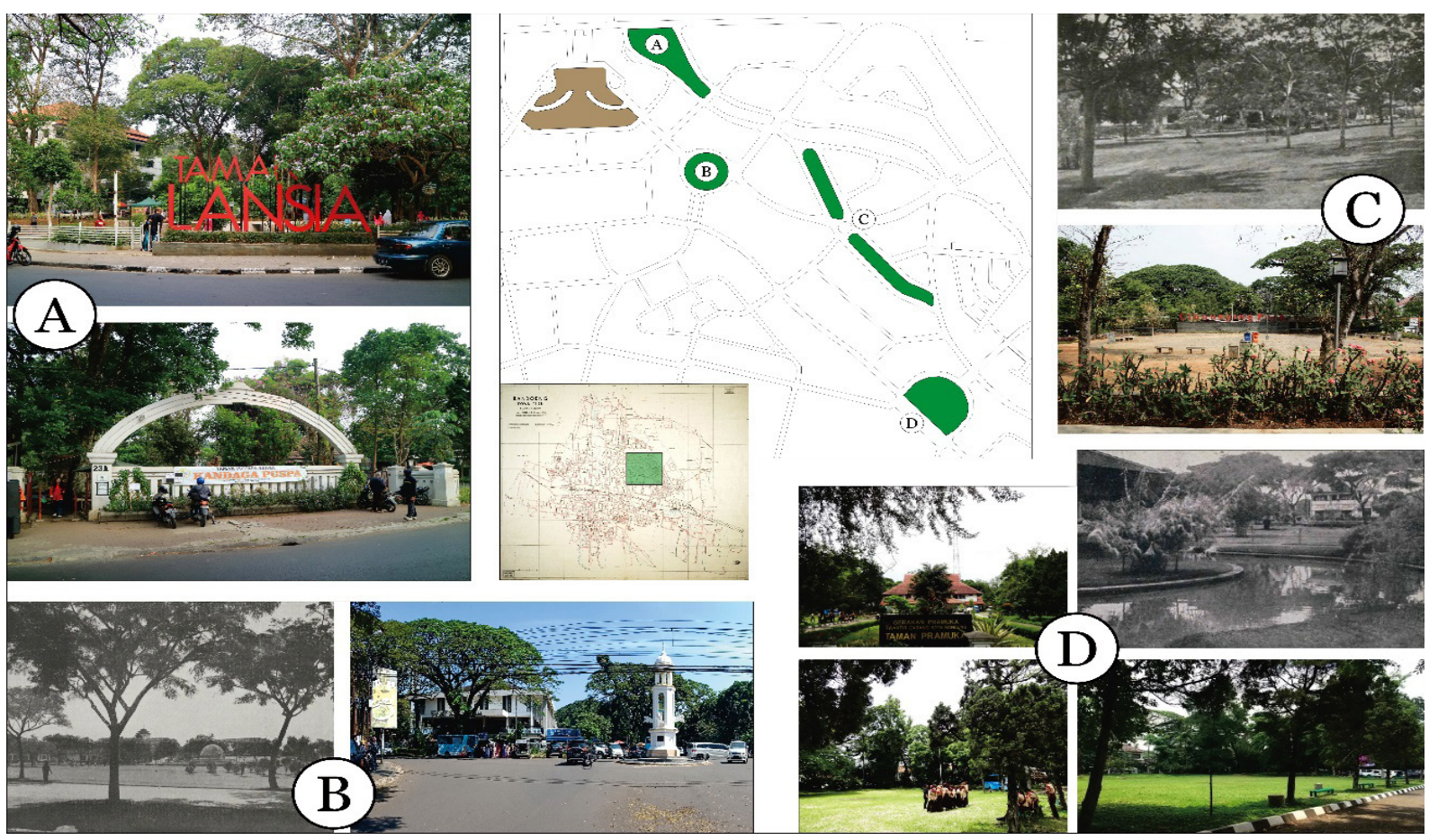

Gambar 5. Keletakan Tjilakiplein, Tjitaroemplein, Tjibeunjing Plantsoen, dan Oranje Nassauplein

Keterangan: A= Tjilakiplein (Taman Lansia \& Taman Kandaga Bunga); B = Tjitaroemplein (Masjid Istiqomah); $\mathrm{C}=$ Tjibeunjing Plantsoen (Taman Cibeunying); D = Oranje Nassauplan (Taman Pramuka)

Sumber:DirekonstruksiolehMiftahulFalahdari Bandoeng: Town Plan, 1945. CollectieKaartenvanColoniaalNederlandschIndie. Inv. D E 29,7. Leiden: Rijskuniversiteit Leiden; ;"Bandoeng als Tuinstad”. Mooi Bandoeng. Maanblad van Bandoeng en Omstreken. Februari 1934. Bandoeng: A. C. Nix \& Co.; "Doorkilk Tiitaroemplantsoen" in Mooi Bandoeng. Maanblad van Bandoeng en Omstreken. Jaargang 6. Nr. 6. Juni. 1938. Bandoeng: A. C. Nix \& Co.; "Oranjeplein" in Mooi Bandoeng. Maanblad van Bandoeng en Omstreken. Jaargang 1. Nr. 5. Nov. 1933. Bandoeng: A. C. Nix \& Co.; "Oranjeplein" in Mooi Bandoeng. Maanblad van Bandoeng en Omstreken. Jaargang 1. Nr. 8. Feb. 1934. Bandoeng: A. C. Nix \& Co.; Dokumentasi Penulis, November 2017; 5 April 2018.

malabar-gunung-puntang/\# more-944Mooi Bandoeng,6 Juni. 1938). Setelah Indonesia merdeka, monumen itu dibongkar karena dipandang tidak sesuai dengan nilainilai susila. Di atas lahan bekas Tjitaroemplein, pemerintah mendirikan Masjid Istiqomah yang kemudian menjadi salah satu masjid yang sangat aktif menjalankan syiar keagamaan di Kota Bandung. Pembongkaran taman tersebut mengakibatkan perubahan ruang terbuka hijau yang digantikan oleh bangunan keagamaan.

Tjibeunjing Plantsoen yang terletak di Tjibeunjing Plantsoen Zuidstraat (sekarang Jalan Cibeunying Utara dan Selatan). Taman yang dibangun oleh Pemerintah Gemeente Bandung berada pada kawasan hijau antara gedung Gouvernements Bedrijven (Gedung Sate) dan kawasan perumahan untuk penduduk golongan Belanda/ Eropa yang banyak dibangun di sekitar Riouwstraat (sekarang Jalan Laksamana R. E. Martadinata). Pada 1980an, Taman Cibeunying diubah menjadi pusat perdagangan tanaman hias di Kota Bandung dan pada September 1986, Pemerintah Kota Bandung secara resmi mengubah nama taman itu menjadi Taman PKK Cibeunying (http:// disparbud.jabarprov. go.id/wisata/destdet.php?id=1089\& lang=idwisata). Sampai sekarang, Tjibeunjing Plantsoen menjadi ruang terbuka hijau koridor jalan yang cukup rindang karena di sisi kiri kanan Jalan Cibuenying ditumbuhi pula oleh aneka jenis pepohonan.

Oranje Nassauplein (sekarang menjadi Taman Pramuka) dibangun sekitar tahun 1920-an dengan bentuk setengah lingkaran. Taman yang berada di antara Bengawanstraat (sekarang Jalan Bengawan) dan Riouwstraat ini dibuat sederhana dengan pepohonan yang ditanam tidak begitu rapat. Di tengah-tengah terdapat sebuah bangunan yang mirip sebagai gazebo yang berdiri di tengah-tengah kolam. Di gazebo inilah, para pengunjung bersantai dengan melakukan minum-minum. Dalam perkembangannya, pada 1940-an, kolam tersebut ditimbun tanah, sedangkan gazebo itu menjadi kantin yang menjual kebutuhan sehari-hari. Pada 1970-an, bangunan tersebut tidak terawat sehingga tidak dapat difungsikan kembali. Oleh karena itu, untuk mengoptimalkan taman yang sebenarnya lebih cenderung sebagai hutan kota itu, pemerintah menjadikannya sebagai pusat kegiatan pramuka di Kota Bandung. Berkaitan dengan itu, nama Oranje Nassauplein pun lebih dikenal dengan nama 
Taman Pramuka. Di seberang gerbang utamanya, terdapat monumen kelapa sebagai lambang gerakan pramuka (Kartodiwirio, 2006: 514).

\section{SIMPULAN}

Dari pemaparan yang telah dilakukan dapat dirumuskan beberapa simpulan sebagai berikut. Pertama, pada masa kolonial, ruang terbuka hijau lebih banyak dibangun di wilayah Bandung Utara karena di wilayah tersebut banyak dibangun pemukiman untuk masyarakat golongan Belanda dan Eropa lainnya. Secara kultural, mereka lebih banyak membutuhkan ruang terbuka hijau sebagai sarana untuk melepaskan rasa penat dari rutinitas. Di wilayah Bandung Selatan, pembangunan ruang terbuka hijau sangat jarang bahkan hampir dikatakan tidak pernah dilakukan karena masyarakat pribumi tidak memiliki budaya yang menjadikan ruang terbuka hijau sebagai bagian dari aktivitas sosialnya. Kedua, pada saat Kota Bandung merayakan hari jadinya, pemerintah kota menjadikan kawasan hijau di lembah Cikapundung sebagai kawasan hutan kota dengan nama Jubileumpark. Kawasan ini memiliki kekayaan flora yang luar biasa sehingga selain difungsikan sebagai kawasan terbuka hijau, juga sebagai pusat penelitian botani. Saat ini, Jubileumpark menjadi kawasan yang dikenal dengan nama Babakan Siliwangi dengan fungsi yang relatif sama, tetapi area wilayahnya lebih sempit dibandingkan pada masa kolonial. Ketiga, Pemerintah Gemeente Bandung mewariskan banyak taman kota kepada Pemerintah Kota Bandung. Sebagian besar taman kota tersebut masih difungsikan sebagai ruang terbuka hijau setelah direvitalisasi oleh Pemerintah Kota Bandung. Sebagin kecil, taman kota warisan kolonial berubah fungsi karena dipandang tidang sesuai dengan budaya lokal, antara lain Tjitaroemplein yang dialihfungsikan menjadi bangunan ibadah (Masjid Istiqomah). Alih fungsi itu dilakukan karena di tengah-tengah taman terdapat monumen dua orang tanpa busana yang sedang "memeluk" bola dunia. Hal itu dianggap sebagai sesuatu yang tidak etis karena memperlihatkan tubuh telanjang.

\section{UCAPAN TERIMA KASIH}

Penulis mengucapkan terima kasih kepada Kementerian Riset, Teknologi, dan Pendidikan Tinggi yang telah mendanai penelitian ini melalui skema Penelitian Dasar pada tahun anggaran 2019. Ucapan terima kasih pun penulis sampaikan kepada Rektor Universitas Padjadjaran, Direktur Penelitian dan Pengabdian Masyarakat Universitas Padjadjaran, serta Dekan Fakultas Ilmu Budaya Universitas Padjadjaran yang telah memfasilitasi sehingga penulis dapat melakukan penelitian ini.

\section{DAFTAR PUSTAKA}

"Bandoeng als Tuinstad". Mooi Bandoeng. Maanblad van Bandoeng en Omstreken. Februari 1934. Bandoeng: A. C. Nix \& Co.

"Doorki|k Tiitaroemplantsoen" in Mooi Bandoeng. Maanblad van Bandoeng en Omstreken. Jaargang 6. Nr. 6. Juni. 1938. Bandoeng: A. C. Nix \& Co.

“Jubileumpark". Mooi Bandoeng. Maanblad van Bandoeng en Omstreken. October 1934. Bandoeng: A. C. Nix \& Co.

"Oranjeplein" in Mooi Bandoeng. Maanblad van Bandoeng en Omstreken. Jaargang 1. Nr. 5. Nov. 1933. Bandoeng: A. C. Nix \& Co..

"Oranjeplein" in Mooi Bandoeng. Maanblad van Bandoeng en Omstreken. Jaargang 1. Nr. 8. Feb. 1934. Bandoeng: A. C. Nix \& Co.

"Pieter Sijthof Park". Mooi Bandoeng. Maanblad van Bandoeng en Omstreken. Jaargang 1. Nr. 8. Feb. 1933. Bandoeng: A. C. Nix \& Co.

"Pieter Sijthof Park". Mooi Bandoeng. Maanblad van Bandoeng en Omstreken. Jaargang 1. Nr. 5. Nov. 1933. Bandoeng: A. C. Nix \& Co.

Allied Geographical Section, "Bandoeng," Monash Collections Online, accessed July 15, 2019, http:// repository.monash.edu/items/show/27141.

Amirulloh, M. (2017). Penggunaan Nama Kota Sebagai Nama Domain di Indonesia. Sosiohumaniora, 19, (1), 8-17.

Bandoeng: Town Plan, (1945). Collectie Kaarten van Coloniaal Nederlandsch-Indie. Inv. D E 29,7. Leiden: Rijskuniversiteit Leiden.

Bataviasch Handelsblad, 30 Juli 1890; Taman Kota Bandung Tempo Dulu. Diaksesdari https://portal. bandung.go.id/taman-kota-bandung-tempo-dulu. Tanggal 1 April 2018. Pukul 0234 WIB

Besluit van Gouverneur Generaal van NederlandscheIndie van 11 October 1856, No. 84.

Besluit van Gouverneur Generaal van NederlandscheIndie van 7 Augustus 1864, No. 18.

Budiman, A., Sulistyantara, B., \& Zain, A.F. (2014). Deteksi perubahan ruang terbuka hijau pada 5 kota besar di Pulau Jawa (Studi kasus: DKI Jakarta, Kota Bandung, Kota Semarang, Kota Jogjakarta, dan Kota Surabaya). Jurnal Lanskap Indonesia, 6, (1), 7-15.

Budiman, H.G. (2015). Perkembangan Taman Kota Di Bandung Masa Hindia Belanda (19181942). Patanjala: Jurnal Penelitian Sejarah dan Budaya, 7, (2), 185-200. 
Dewiyanti, D. (2011). Ruang Terbuka Hijau Kota Bandung: Suatu Tinjauan Awal Taman Kota Terhadap Konsep Kota Layak Anak. Majalah Online Unikom, 7, (1).

Falah, Miftahul. (2018). Pertumbuhan Morfologi KotaKota Pusat Pemerintahan di Priangan Abad $X X$-Abad XXI. Disertasi. Jatinangor: Program Pascasarjana, Fakultas Ilmu Budaya, Universitas Padjadjaran

Garraghan, J. Gilbert. (1957). A Guide to Historical Method. New York: Fordham University.

Gottschalk, Louis. (1969). Understanding History; A Primer of Historical Method. $2^{\text {nd }}$ Edition. New York: Alfred A, Knoff.

Hakim, R. (2003). Arsitektur Lansekap: Manusia, Alam dan Lingkungan. Jakarta: Penerbit Universitas Trisakti.

Herlina, Nina. (2008). Metode Sejarah. Bandung: Satya Historika.

Het Ijzermanpark te Bandoeng, (1925). Collectie Koninklijk Insituut Taal-, Land-, en Volkenkunde (KITLV). Inv. Nr. 34882. Leiden: Rijskuniversiteit Leiden.

Het Ijzermanpark teBandoeng,(1930). Collectie Koninklijk Insituut Taal-, Land-, en Volkenkunde (KITLV). Inv. Nr. 143590. Leiden: Rijskuniversiteit Leiden.

Het Paleis van de Legercommandant aan het Insulinde Park te Bandoeng, (1920). Collectie Koninklijk Insituut Taal-, Land-, en Volkenkunde (KITLV). Inv. Nr. 1400613. Leiden: Rijskuniversiteit Leiden.

Indira, D., Ismanto, S.U., \& Santoso, M.B. (2013). Pencitraan Bandung Sebagai Daerah Tujuan Wisata: Model Menemukenali Ikon Bandung Masa Kini. Sosiohumaniora, 15, (1), 45-54.

Indonesia. (2009). Peraturan Menteri (Permen) Pekerjaan Umum Nomor 12/PRT/M 2009.

Ingin Mengajak Jalan-Jalan HewanPeliharaan Anda? BawaSajake Pet Park. Diaksesdarihttp://www. wisatabdg.com/-2014/10/ingin-mengajak-jalanjalan-hewan.html. Tanggal 24 Sep-tember 2015. Pukul 00.59 WIB

Inilah Taman-Taman Tematik di Kota Bandung. Diakses dari http://www.wisatabdg. com/2014/09/inilahtaman-tematik-di-kota-bandung.html. Tanggal 23 September 2015. Pukul 00.11 WIB

Kartodiwirio, S. K. (2006). Bandung: kilas peristiwa di mata filatelis: sebuah wisata sejarah. Kiblat Buku Utama.
Kunto, Haryoto. (1984). Wajah Bandoeng Tempo Doloe. Bandung: Granesia.

Kuntowijoyo, (1995). Pengantar Ilmu Sejarah. Yogyakarta: Yayasan Bentang Budaya.

Kurniati, P. S. (2016). "Implementasi Kebijakan Penataan Ruang Di Kota Bandung" dalam Jurnal Ilmu Politik dan Komunikasi, VI, (2).

Mooi Bandoeng,Feb. 1933; February 1934; October 1934; 6 Juni. 1938.

Pramiadi, Alde. 2010. Sejarah Taman Kota di Bandung. Diakses dari http://aldes91. blogspot.com/2010/01/ sejarah-taman-kota-di-bandung.html. Tanggal 8 Mei 2019. Pukul 19.27 WIB.

Puspitojati,T.\&Samsoedin,I.(2015). KajianPengembangan Ruang Terbuka Hijau di Kota Bandung. Jurnal Analisis Kebijakan Kehutanan, 12, (1), 55-66.

Rahmy, W. A., Faisal, B., \& Soeriaatmadja, A. R. (2012). Kebutuhan Ruang Terbuka Hijau Kota pada Kawasan Padat, Studi Kasus di Wilayah Tegallega, Bandung. Jurnal Lingkungan Binaan Indonesia, 1, (1), 27-38.

Reitsma,.S. A. (1926). Bandoeng; The Moun-tain City of Netherlands India. Batavia: G. Kolff.; Bandoengsche Administratie Mij. De Jaarbeurs en Bandoeng 1921. Bandoeng: Visser \& Co.

Sofianto, K. (2014). Garut Pada Masa Pemerintahan Pendudukan Jepang (1942-1945). Sosiohumaniora, 16, (1), 70-86.

Staatsblad van Nederlandsche-Indie 1864 Nomor 114.

Stanley, B. W., Stark, B. L., Johnston, K. L., \& Smith, M. E. (2012). Urban open spaces in historical perspective: A transdisciplinary typology and analysis. Urban Geography, 33, (8), 1089-1117.

Stasiun Radio Malabar - GunungPuntang. Diakses dari https://mooibandoeng.com/2013/06/27/ stasiunradio-malabar-gu-nung-puntang/\# more-944. Tanggal 1 April 2018. Pukul 12.47 WIB

Suganda, H. (2007). Jendela Bandung: Pengalaman Bersama Kompas. Penerbit Buku Kompas.

Taman Cibeunying. Diakses dari http://disparbud. jabarprov.go.id/wisata/destdet.php?id= 1089\&lang=idwisata. Tang-gal 30 Maret 2018. Pukul 11.31 WIB

Taman Kota Bandung Tempo Dulu. Diaksesdari https:// portal.bandung.go.id/ taman-kota-bandungtempo-dulu. Tanggal 1 April 2018. Pukul 0234 WIB. 